\title{
Kepatuhan Ibu Hamil Dalam Mengkonsumsi Tablet Fe (Ferrum) Terhadap Kejadian Anemia Di Desa Langgenharjo Kecamatan Juwana
}

\author{
Yulia Pratiwi ${ }^{\mathrm{a}, 1 *}$, Tya Safitri ${ }^{\mathrm{a}, 2}$ \\ ${ }^{a}$ Program Studi SI Farmasi, STIKES Cendekia Utama Kudus, Kudus, Jawa Timur, Indonesia \\ Iyuliapratiwi.337@gmail.com,2tyasafitri151@gmail.com \\ *korespondensi penulis
}

\begin{tabular}{|c|c|}
\hline INFO ARTIKEL & ABSTRAK \\
\hline $\begin{array}{l}\text { Diterima: } \\
\text { I2-OI-202I } \\
\text { Disetujui : } \\
\text { I9-0I-202I }\end{array}$ & $\begin{array}{l}\text { Selama kehamilan, tubuh wanita memerlukan lebih banyak darah untuk } \\
\text { mendukung pertumbuhan bayi. Wanita hamil berisiko tinggi mengalami anemia } \\
\text { defisiensi besi. Wanita hamil membutuhkan zat besi tambahan untuk memasok } \\
\text { oksigen ke bayi. Untuk itulah wanita hamil perlu mengkonsumsi Fe untuk } \\
\text { mensuplai kebutuhan darah. Kepatuhan dalam konsumsi tablet Fe merupakan }\end{array}$ \\
\hline $\begin{array}{l}\text { Kata kunci : } \\
\text { Kepatuhan; } \\
\text { Ibu hamil; } \\
\text { Konsumsi; } \\
\text { Tablet Fe. }\end{array}$ & $\begin{array}{l}\text { hal yang perlu diperhatikan. Tujuan penelitian ini adalah untuk mengetahui } \\
\text { bagaimana pengaruh kepatuhan ibu hamil dalam konsumsi tablet Fe terhadap } \\
\text { tingkat kejadian anemia di Desa Langgenharjo, Kecamatan Juwana. } \\
\text { Penelitian ini menggunakan jenis rancangan observasional analitik dengan } \\
\text { pendekatan cross sectional, observasi atau pengumpulan data, serta pemberian } \\
\text { edukasi di Desa Langgenharjo. Metode yang digunakan dalam penelitian adalah } \\
\text { metode kuantitatif yang bersifat deskriptif non eksperimental. Instrumen } \\
\text { penelitian yang digunakan dalam peneltian ini berupa kuesioner dan edukasi. } \\
\text { Data dianalisis dengan SPSS } 22,0 \text { dengan menggunakan uji normalitas, uji Chi- } \\
\text { Square. Hasil penelitian menunjukan bahwa tidak terdapat hubungan antara } \\
\text { kepatuhan ibu hamil dalam mengkonsumsi tablet Fe terhadap tingkat kejadian } \\
\text { anemia dengan p (value) } 0,229 \text {. }\end{array}$ \\
\hline
\end{tabular}

Keywords :

Compliance;

Pregnant women;

Consumption;

Fe Tablet.

\begin{abstract}
During pregnancy, a woman's body needs more blood to support the baby's growth. Pregnant women are at high risk for iron deficiency anemia. Pregnant women need extra iron to supply oxygen to the baby. For communication, pregnant women need to take iron to supply blood. Compliance with the consumption of $\mathrm{Fe}$ tablets is something that needs attention. The purpose of this study was to see how compliance of pregnant women in consuming $\mathrm{Fe}$ tablets on the incidence of anemia in Langgenharjo Village, Juwana District.

This research used an analytic observational design with a cross sectional approach, observation or data, as well as providing education in Langgenharjo Village. The method used in this research is quantitative quantitative which is descriptive non-experimental. The research instruments used in this research were questionnaires and education. Data were analyzed using SPSS 22.0 using normality test, Chi-Square test. The results showed that there was no effect between pregnant women in consuming $\mathrm{Fe}$ tablets on the incidence rate of anemia with $\mathrm{p}$ (value) 0.229 .
\end{abstract}

This is an open access article under the CC-BY-SA license.

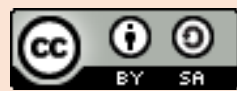

\section{Pendahuluan}

Selama kehamilan, tubuh wanita memerlukan lebih banyak darah untuk mendukung pertumbuhan bayi (Elhasan et al. 2010). Jika tidak mendapatkan cukup zat besi atau nutrisi tertentu lainnya, tubuh mungkin tidak dapat menghasilkan jumlah sel darah merah yang dibutuhkan untuk membuat darah tambahan ini (Kedir et al., 2013).

Mengalami anemia ringan saat hamil adalah hal yang normal. Tetapi wanita hamil mungkin mengalami anemia yang lebih parah karena kadar zat 
besi atau vitamin yang rendah atau karena alasan lain. Kekurangan anemia bisa membuat tubuh merasa lelah dan lemah. Jika parah tetapi tidak diobati, dapat meningkatkan risiko komplikasi serius seperti persalinan prematur (Mei et al., 20I4). Hal tersebut yang menyebabkan wanita hamil berisiko tinggi mengalami anemia defisiensi besi. Anemia adalah suatu kondisi di mana tubuh tidak memiliki cukup sel darah merah yang sehat untuk membawa oksigen yang cukup ke jaringan tubuh.

Tubuh menggunakan zat besi untuk membuat hemoglobin, protein dalam sel darah merah yang membawa oksigen ke jaringan tubuh. Selama kehamilan, tubuh membutuhkan dua kali lipat jumlah zat besi yang dibutuhkan wanita tidak hamil. Tubuh membutuhkan zat besi ini untuk membuat lebih banyak darah memasok oksigen ke bayi. Jika Anda tidak memiliki cukup simpanan zat besi atau mendapatkan cukup zat besi selama kehamilan, maka tubuh dapat mengalami anemia defisiensi besi (Liu et al., 2013).

Anemia berat selama kehamilan meningkatkan risiko kelahiran prematur, melahirkan bayi dengan berat badan rendah, dan depresi pascapersalinan. Beberapa penelitian juga menunjukkan peningkatan risiko kematian bayi sebelum atau sesudah lahir.

Anemia adalah kekurangan kadar hemoglobin (Hb) dalam darah yang disebabkan karena kekurangan zat gizi. Anemia gizi besi adalah anemia yang disebabkan karena kekurangan zat besi $(\mathrm{Fe})$ dalam darah (Fathonah, 2016). Anemia defisiensi besi pada ibu hamil merupakan problema kesehatan yang dialami oleh wanita seluruh dunia terutama di Negara Indonesia. Kadar hemoglobin pada ibu hamil merupakan hal yang fisiologis, dan apabila tidak ditangani akan menjadi patologis yang akan membahayakan kesehatan ibu dan janin. Kadar hemoglobin normal pada ibu hamil adalah diatas II gr/dL, apabila hemoglobin ibu hamil kurang dari I I gr/dL dapat dikatakan anemia. Anemia pada ibu hamil yang paling sering adalah anemia defisiensi besi. (Wulandari, 2018).

Di Indonesia prevalensi pemberian tablet $\mathrm{Fe}$ pada ibu hamil sebesar 37,I\%. Pemberian tablet Fe pada tahun 2015 sebesar $85,17 \%$. Dalam hal ini presentase mengalami peningkatan dibandingkan pada tahun 2014 hanya sebesar $85,1 \%$. Pemerintah sudah melakukan program penanggulangan anemia pada ibu hamil yaitu dengan memberikan tablet $\mathrm{Fe}$ sebanyak 90 tablet kepada ibu hamil dengan tujuan untuk menurunkan angka anemia pada ibu hamil (Kementrian Kesehatan RI, 2015).

Kepatuhan dalam konsumsi tablet $\mathrm{Fe}$ merupakan hal yang perlu diperhatikan. Meskipun banyak laporan bahwa cakupan ibu hamil yang mendapatkan tablet Fe dengan baik, tetapi jika tidak dikonsumsi oleh ibu hamil, maka efek yang diinginkan tidak akan tercapai. Secara umum derajat kesehatan yang diharapkan akan terlambat peningkatannya (Kementrian Kesehatan RI, 20II).

Ketidakpatuhan ibu hamil dalam konsumsi tablet $\mathrm{Fe}$ dapat mencerminkan seberapa besar ibu hamil akan terkena anemia. Pemberian informasi pada ibu hamil tentang anemia sangat diperlukan. Apabila pengetahuan ibu hamil meningkat, maka akan mempengaruhi kehamilannya karena pengetahuan tentang anemia sangatlah penting sehingga ibu hamil patuh minum tablet Fe. Memperhatikan hal tersebut maka disini saya sebagai penulis ingin mengetahui bagaimana kepatuhan ibu hamil dalam konsumsi tablet Fe terhadap kejadian anemia di Desa Langgenharjo, Kecamatan Juwana.

\section{Metode}

Penelitian ini menggunakan jenis rancangan observasional analitik dengan pendekatan cross sectional, observasi atau pengumpulan data, serta pemberian edukasi di Desa Langgenharjo. Metode yang digunakan dalam penelitian adalah metode kuantitatif yang bersifat deskriptif non eksperimental.

Penelitian ini dilaksanakan pada bulan Maret 2020 di Desa Langgenharjo Kecamatan Juwana.

Populasi penelitian ini adalah ibu hamil yang mengkonsumsi tablet $\mathrm{Fe}$ di Desa Langgenharjo Kecamatan Juwana. Pengambilan sampel dengan cara non probability sampling dengan metode purposive sampling dan memenuhi kriteria inklusi dan eksklusi.

Instrumen penelitian yang digunakan dalam peneltian ini berupa kuesioner dan edukasi. Teknik yang digunakan dalam penelitian ini adalah data yang dikumpulkan berupa data primer dan data sekunder untuk mengetahui kepatuhan ibu hamil dalam mengkonsumsi tablet $\mathrm{Fe}$ terhadap kejadian anemia di Desa Langgenharjo pada bulan maret 2020.

Data dianalisis dengan SPSS 22,0 dengan menggunakan uji normalitas, uji Chi-Square. 


\section{Hasil dan Pembahasan}

Tabel I Distribusi frekuensi karakteristik berdasarkan umur, pendidikan, pekerjaan, dan usia kehamilan

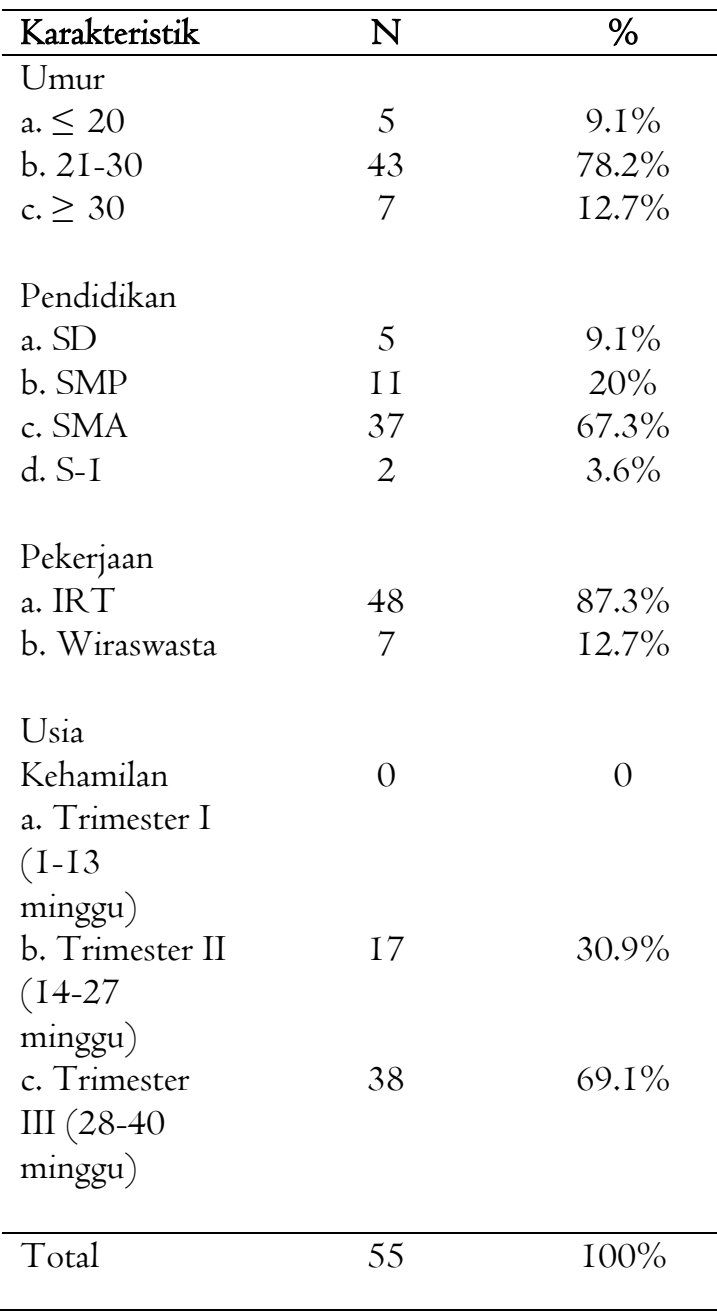

Pada tabel I diatas dari 55 responden ibu hamil yang masuk dalam kategori umur terbanyak yaitu kategori dewasa muda (2I-30 tahun) sebanyak 43 responden $(78,2 \%)$. Hal tersebut dikarenakan pada wanita umur 20-30 tahun memasuki umur paling subur, sehingga ideal bagi wanita untuk hamil. Mayoritas responden berpendidikan SMA sebanyak 67 responden $(67,3 \%)$, bahkan masih ada yang berpendidikan SMP sebanyak II responden $(20 \%)$ dan SD sebanyak 5 responden $(9,1 \%)$. Hal ini dikarenakan masyarakat di Desa Langgenharjo ratarata bekerja sebagai petani, perikanan, dan wiraswata. Syarat pekerjaan mereka tidak memerlukan ijazah berpendidikan tinggi (sarjana, d3, dll), ditambah biaya pendidikan yang mahal untuk melanjutkan pendidikan yang lebih tinggi menjadi pertimbangan mereka. Sebagian besar di Desa Langgenharjo yang menjadi responden dalam penelitian ini pekerjaannya paling banyak sebagai IRT yaitu 48 responden $(87,3 \%)$ dan untuk mencukupi kebutuhan sehari- hari dihasilkan dari para suami mereka. Adapun yang memutuskan untuk bekerja sebagai wiraswata seperti pedagang hanya 7 responden (I2,7\%). Hal tersebut dikarenakan para ibu-ibu di Desa Langgenharjo lebih memilih dapat mengurus anak-anak dirumah, karena pada hakekatnya wanita adalah seorang yang bertanggung jawab mengurus rumah dan anak. Usia kehamilan ibu hamil di Desa Langgenharjo saat ini kebanyakan di Trimester III (usia 28-40 minggu) yaitu 38 responden (69,I\%). Pada kehamilan Trimester III biasanya ibu hamil akan mengalami rasa sakit dan pembengkakan disekujur tubuhnya, sebagian ibu hamil mungkin mengalami kecemaasan dalam kehamilan dan cemas yang dialaminya membuat sulit tidur. Hal tersebut yang menyebabkan ibu hamil Trimester III akan lebih rutin untuk berobat.

\section{Kepatuhan Ibu Hamil}

Salah satu cara untuk mengukur kepatuhan adalah dengan koesioner. Koesioner MMAS digunakan untuk menilai kepatuhan mengkonsumsi obat dengan rentang nilai 0-8. Kategori respon terdiri dari ya dan tidak. Untuk item nomer I sampai 4 dan 6 sampai 7 nilai I untuk jawaban tidak. Item nomer 5 nilai I untuk jawaban ya dan 5 skala likert untuk nomer 8 dengan nilai I untuk jawaban tidak pernah (Mursiani, Ermawati, \& Oktaviani, 2013).

Tabel 2 Kepatuhan Ibu Hamil

\begin{tabular}{llcc}
\hline $\begin{array}{l}\text { Tingkat } \\
\text { Kepatuhan }\end{array}$ & Kategori & n & $\%$ \\
\hline $\begin{array}{l}\text { Kepatuhan } \\
\text { Tinggi }\end{array}$ & Skor 8 & 5 & $9.1 \%$ \\
$\begin{array}{l}\text { Kepatuhan } \\
\text { Menengah }\end{array}$ & Skor $6-<8$ & 43 & $78.2 \%$ \\
$\begin{array}{l}\text { Kepatuhan } \\
\text { Rendah }\end{array}$ & Skor $<6$ & 7 & $12.7 \%$ \\
& & &
\end{tabular}

\begin{tabular}{lll}
\hline Total & 55 & $\mathrm{I} 00 \%$
\end{tabular}

Berdasarkan tabel 2 diatas dapat dilihat kepatuhan ibu hamil yang mengkonsumsi tablet $\mathrm{Fe}$ rata-rata tingkat kepatuhannya adalah menengah yang artinya masih dalam kategori patuh mengkonsumsi tablet $\mathrm{Fe}$ pada kisaran I tablet perhari yaitu sebanyak 43 responden (78,2\%). Adapun kepatuhan kategori rendah yaitu 7 responden (I2,7\%) dikarenakan kurangnya kesadaran ibu untuk mengkonsumsi tablet $\mathrm{Fe}$, selain itu efek samping dari tablet $\mathrm{Fe}$ yang membuat mual sehingga beberapa ibu hamil malas untuk mengkonsumsi secara rutin. 
Banyak faktor yang dapat menyebabkan anemia defisiensi besi, termasuk kekurangan asupan zat besi dan protein dari makanan, gangguan penyerapan di usus, akut dan kronis perdarahan, dan peningkatan kebutuhan zat besi seperti pada wanita hamil, masa pertumbuhan dan masa pemulihan dari sakit. Hal ini yang menyebabkan wanita hamil harus mengkonsumsi $\mathrm{Fe}$, dalam memberikan suplai kebutuhan zat besi bagi tubuhnya. Ketidakpatuhan ibu hamil dalam mengkonsumsi (Fe) dapat meningkatkan resiko terjadinya anemia (Mary et al., 2018).

Memberikan informasi tentang anemia akan meningkatkan pengetahuan mereka tentang anemia, karena pengetahuan memainkan peran yang sangat penting agar wanita hamil dapat patuh minum zat besi $(\mathrm{Fe})$. Secara umum, ketidakpatuhan dapat menyebabkan peningkatan risiko masalah kesehatan atau memperburuk rasa sakit yang diderita. Terdapat bukti penelitian yang menunjukkan bahwa 20\% dari kejadian rawat inap akibat anemia adalah akibatnya ketidakpatuhan pasien terhadap aturan pengobatan (Gebre et al., 2015).

\section{Kejadian Anemia}

Untuk mengetahui tingkat kejadian anemia pada ibu hamil dapat dilihat pada tabel 3 yang menyatakan kadar $\mathrm{Hb}$ ibu hamil di Desa Langgenharjo paling banyak $\geq$ II gr/dL yang artinya tidak terkena anemia. Hal tersebut dikarenakan makan-makanan kaya zat besi bagi ibu hamil sudah tercukupi, ditambah lagi kepatuhan untuk mengkonsumsi tablet $\mathrm{Fe}$ sudah memasuki kategori menengah yang artinya patuh.

Tabel 3 Kadar Hb Ibu Hamil

\begin{tabular}{lll}
\hline $\mathrm{Hb}$ & $\mathrm{N}$ & $\%$ \\
\hline a. $\geq$ I I gr/dL (tidak anemia) & $3 \mathrm{I}$ & $56.4 \%$ \\
b. 9-I0 gr/dL (anemia ringan) & 24 & $43.6 \%$ \\
c. 7-8 gr/dL (anemia sedang) & 0 & 0 \\
\hline Total & 55 & $100 \%$ \\
\hline
\end{tabular}

Anemia sering terjadi pada wanita hamil karena kekurangan zat besi. Kekurangan zat besi ini disebabkan karena terjadi peningkatan kebutuhan zat besi memenuhi kebutuhan ibu (mencegah kehilangan darah selama persalinan) dan pertumbuhan janin. Ironisnya, diperkirakan kurang dari 50\% ibu hamil tidak memiliki cadangan zat besi yang cukup selama kehamilan, sehingga risiko kekurangan zat besi atau anemia meningkat karena kehamilan. Anemia dipengaruhi oleh banyak faktor, termasuk usia kehamilan, pendidikan ibu, keluarga pendapatan, jarak kehamilan, paritas, konsumsi tablet penambah darah $(\mathrm{Fe})$, dan riwayat penyakit. Anemia pada trimester I dan II tidak berhubungan dengan berat badan rendah dan kelahiran prematur, sedangkan anemia pada trisemester III memiliki pengaruh terhadap gejala berat badan rendah dan kelahiran prematur (Sengpiel et al., 2014).

\section{Kepatuhan Ibu Hamil Dalam Konsumsi Tablet Fe Terhadap Kejadian Anemia}

Tabel 4 Kepatuhan Ibu Hamil Dalam Konsumsi Tablet Fe Terhadap Kejadian Anemia

\begin{tabular}{lc}
\hline Variabel $(\mathbf{N}=\mathbf{5 5})$ & $\boldsymbol{P}$ \\
\hline Tingkat kepatuhan &, 229 \\
\hline
\end{tabular}

Berdasarkan tabel 8 diatas diperoleh nilai $\mathrm{p}$ (value) $0,229 \geq 0,05$ yang artinya tidak ada hubungan dengan tingkat kejadian anemia, hal tersebut dikarenakan ibu hamil di Desa Langgenharjo selalu mendengarkan informasi tentang anemia yang diberikan dari petugas kesehatan dan patuh mengonsumsi tablet $\mathrm{Fe}$, serta dilihat dari $\mathrm{Hb}$ ibu hamil tersebut masuk kategori tidak anemia $(\geq$ II gr/dL), sehingga kepatuhan ibu hamil tidak ada hubungannya dengan kejadian anemia.

Adapun penyebab kurang patuhnya ibu hamil dalam mengkonsumsi tablet $\mathrm{Fe}$ yaitu dipengaruhi oleh efek samping yang kurang nyaman dirasakan oleh ibu hamil ketika mengkonsumsi tablet $\mathrm{Fe}$, seperti mual dan muntah (Amni, 20I7).

Menurut Yeni et al. (2016), faktor-faktor yang mempengaruhi kepatuhan ibu hamil mengonsumsi zat besi $(\mathrm{Fe})$ meliputi pengetahuan ibu hamil tentang anemia dan kegunaan zat besi. Informasi ini diperoleh dari penyuluhan yang diberikan oleh bidan saat ibu hamil melakukan pemeriksaan kehamilan. Selain itu latar belakang pendidikan ibu hamil juga sangat berpengaruh terhadap kepatuhan ibu hamil minum tablet zat besi. Pengetahuan responden yang rendah tentang anemia dapat menyebabkan ketidakpahaman tentang berbagai kelainan dan penyakit yang menyertai selama kehamilan, khususnya tentang anemia. Hal ini menyebabkan kurangnya pengobatan dan pencegahan anemia selama kehamilan. Pengetahuan yang rendah mengakibatkan responden tidak memperhatikan makanan dan konsumsi nutrisi, terutama konsumsi tablet Fe untuk ibu hamil jadi resiko anemia besar.

\section{Simpulan dan Saran}

Hasil penelitian menunjukan bahwa tidak terdapat hubungan antara kepatuhan ibu hamil dalam 
konsumsi tablet Fe terhadap tingkat kejadian anemia dengan $\mathrm{p}$ (value) 0,229.

\section{Daftar Pustaka}

Amni S.N .(2017). Hubungan antara Kepatuhan Konsumsi Tablet Besi, Status Gizi, dan Pola Makan dengan Kejadian Anemia pada Ibu Hamil. Diterbitkan. Makasar: Fakultas Kedokteran Universitas Hasanuddin Makasar

Elhassan EM, Abbaker AO, Haggaz AD, Abubaker MS, Adam I. (2010). Anemia and low birth weight in Medani, Hospital Sudan. BMC Res Notes. 2010;28(3):181.

Fathonah, Siti. (2016). Gizi \& Kesehatan untuk Ibu Hamil. Erlangga : Jakarta.

Gebre A, Afework M, Belachew E. (20I5). Assessment of factors associated with adherence to iron-folic acid supplementation among urban and rural pregnant women in North Western Zone of Tigray, Ethiopia: comparative Study. Int J Nutr Food Sci. 20I5;4(2):I6I-8.

Kedir H, Berhane Y, Worku A. (2013). Chewing and restrictive dietary behaviors are associated with anemia among pregnant womenin high prevalence rural communities in eastern Ethiopia. PLoS One. 2013; 4;8(I I):e7860I.

Kementria Kesehatan RI. (20I I). Profil Kesehatan Indonesia 20IO. Jakarta: Kementrian Kesehatan RI.

Kementrian Kesehatan RI. (20I5). Profil Kesehatan Indonesia 2015. Jakarta: Kementrian Kesehatan RI.

Liu JM, Mei Z, Ye R, Serdula MK, Ren A, Cogswell ME. (2013). Micronutrient supplementation and pregnancy outcomes: double-blind randomized controlled trial in China. JAMA Intern Med. 2013;I73(4):276-82

Mary Wanjira Kamau,Waithira Mirie, and Samuel Kimani, (2018). Compliance with Iron and folic acid supplementation (IFAS) and associated factors among pregnant women: results from a crosssectional study in Kiambu County, Kenya. BMC Public Health. 2018; 18: 580.

Mei Z, Serdula MK, Liu JM, Flores-Ayala RC, Wang L, Ye R, Grummer-Strawn LM. (20I4). Iron-containing micronutrient supplementation of Chinese women with no or mild anemia during pregnancy improved iron status but did not affect perinatal anemia. J Nutr. 2014;144(6):943-8.
Mursiani, A., Ermawati, N., Oktaviani, N. (2013). Gambaran Penggunaan Obat Dan Kepatuhan Mengkonsumsi Obat Pada Penyakit Hipertensi Di Instlasi Rawat Jalan RSUD Kraton Kabupaten Pekalongan Tahun 2013

Sengpiel V, Bacelis J, Myhre R, (20I4), Folic acid supplementation, dietary folate intake during pregnancy and risk for spontaneous preterm delivery: a prospective observational cohort study . BMC Pregnancy Childbirth, 2 November 2014.

Wulandari, Ratna. (2018). Pengaruh kepatuhan ibu hamil dalam mengkonsumsi tablet fe terhadap kadar hb ibu hamil trimester iii, vol 8.

Yeni Andriyani, Supriyadi Hari Respati, Okid Paramaastirin. (2016). Effectiveness of Pregnant Woman Class in The Prevention of Pregnancy Anemia in Banyuwangi, East Java, J. Of Maternal anda Child Health, Vol I No. 4 2016.pp, 230-24I. 